\title{
路面性状による飛行場コンクリート舗装の老朽度評価

\author{
DETERIORATION EVALUATION OF AIRFIELD CONCRETE PAVEMENT \\ BY SURFACE CONDITION
}

\author{
木暮敬二*・藤本一男**・酒井隆***・松田隆繁*** \\ By Keiji KOGURE, Kazuo FUJIMOTO, Takashi SAKAI and Takashige MATSUDA
}

\begin{abstract}
The Defense Agency has a large number of airfield concrete pavements that are approaching the ent of their service lives. As a result, the maintenance required to keep these pavements in service is steadily increasing and it is very important to quantify the deterioration of pavement. In this paper, an equation for deterioration evaluation of airfield concrete pavement by surface conditions was developed. The value obtained from the developed equation was called Pavement Deterioration Index (PDI). The accuracy of PDI method was examined by the past data of surface condition survey that carried out when the pavement was rehabilitated and it is shown that PDI method can be used for the deterioration evaluation of airfield concrete pavement.

Keywords : airfield concrete pavement, deterioration evaluation, surface condition, surface survey, method of quantification
\end{abstract}

\section{1. まえがき}

飛行場の各種構造物や施設のうち，基本施設とよばれ る滑走路等の舗装構造物は厳しい交通荷重や気象条件に さらされており, 他の構造物に比べて老朽化の度合が大 きい，航空機の安全運行のためには，舗装がある水準以 上の供用性を保持している必要がある. しかし，航空機 の安全運行が損なわれる舗装の破損程度の判断はかなり 難しく，個人の主観的な判断が入りやすく，客観性に欠 けるきらいがある．舗装の破損やそれに伴う補修時期は 老朽度あるいは供用性を数量化した客観的な指標を用い て判断する必要がある1). 防衛庁の飛行場は建設後数十 年を経過しているものが多く，老朽化が進んでいる。ま た，使用する航空機の相違等のため他機関の供用性評価 式を利用できない. そのため舗装の破損に基づく老朽度 を合理的に評価し，補修時期を判断することが重要なこ ととなっている.

本研究は, 飛行場コンクリート舗装の路面の破損に関 する主観的な視察調査(アンケート調査による定性評価)

* 正会員 工博 防衛大学校教授 土木工学教室 （干239 横須賀市走水 1-10-20）

** 正会員 工博 防衛庁技術研究本部第 4 研究所築城研究 室長 ( 1229 相模原市㴊野辺 2-9-54)

*** 防衛施設庁建設部技官 ( 1107 港区赤坂 9-7-54)
と路面性状調査（実測調査による定量評価）とを数量化 理論の手法 ${ }^{2)}$ を用いて結びつけ，コンクリート舗装路面 の破損状態に基づく老朽度の合理的な診断指標を得るこ とを目的としている.

第 1 に，老朽度評価式を作成するための基本デー夕を 入間飛行場において収集する。このデータは客観的な定 量值としての路面性状調査および主観的な定性評価とし ての視察調査によって得られる. 第 2 に, 数量化理論 II 類 ${ }^{2}$ を用いて，視察による主観的な定性評価を客観的な 評価値に数量化することを試みる．第 3 に，数量化され た評価値と実測による定量評価結果とから，舗装の老朽 度を表わす評価式を作成する. 第 4 に, 得られた評価式 を他機関のそれと比較検討するとともに既存調査資料お よび舗装補修実績と比較することによってその妥当性を 検討する。

従来，老朽度あるいは供用性評価式の作成の基本とな る定性的なデー夕は舗装技術者のみによって収集される 場合が多かった1). 本研究においては，舗装技術者のほ かに, パイロット, 飛行場管理者およびその他の人の視 察調査への参加によって幅広いデータの収集に努めた. また, 老朽度評価式に取り入れる舗装破損項目は, 将来 機器調査によって測定可能な項目を選定した. 


\section{2. 既往の評価方式}

飛行場および道路を含めて, 路面の破損による舗装の 供用性の評価方式は 2 つに大別することができる．1つ は路面破損の実測値を組み込んだ単純な評価式による方 法である.この方式の先駆となったのが AASHO の道 路試験に基づいたPSI (Present Serviceability Index $)^{3)}$ であり，この流れを汲むわが国の代表的なもの が建設省の道路に関する MCI (Maintenance Control Index $)^{4)}$ と飛行場に関する運輸省のPRI (Pavement Rehabilitation Index $)^{5)}$ である。これらは，ひびわれ， 目地部の破損, 段差等の路面の破損項目の中から, 評価 に与える影響が大きいと考えられるものを数項目選定 し, 供用性の評価式を作成し, 破損項目の実測値を代入 して供用性の指標を得るとともに補修の判断基準として いる.

第 2 の評価方式はアメリカ空軍の PCI (Pavement Condition Index $)^{6,7)}$ の流れを汲むものである. 舗装路 面を多くの舗装技術者に視察させ，路面性状の劣化の度 合に応じてあらかじめ設定されている減点値のうち実際 の路面性状項目に対応するものをいくつか選び，減点方 式で舖装の残存供用性を評価するものである，この方式 を用いる場合には常に多数の熟練した舗装技術者を必要 とする.

本研究での評価方式は，舗装技術者の層の問題あるい は利用の単純さを考慮して，上記の第 1 の範疇に入るも のとした。

\section{3. 路面性状調査と視察調査}

図一1に調查およびデータ分析の全体的な流れを示し た．図一1に示すように老朽度評価式のための基本デー 夕は 2 つ調查によって得られた。

今回の調查場所として, 多様な破損形態と破損程度が 含まれていることおよび視察調査を依頼した人の利便性 を考慮して，埼玉県の入間飛行場を選んだ。まず，運輸 省航空局の空港舗装補修要領（案）に基づいて，ひびわ れ，目地の破損，段差および平坦性等の路面性状調査を 行い, 多様な破損形態と破損程度を含む 30 区画を対象 調査区画として設定した，各調查区画の大きさは約 $18.3 \times 22.9 \mathrm{~m}$ であり，ほぼ $3 \times 3=9$ 枚のコンクリート 版から構成されている.

\section{（1）路面性状調査（定量評価）}

設定した 30 の調査区画についての空港舗装補修要領

（案）による路面性状調査としての定量測定項目は次の ようである.

(1) ひびわれ係数 $(\mathrm{CR})$ ：調査区画内のひびわれ総 延長 $(\mathrm{cm})$ を測定し，次のように定義したひびわれ係

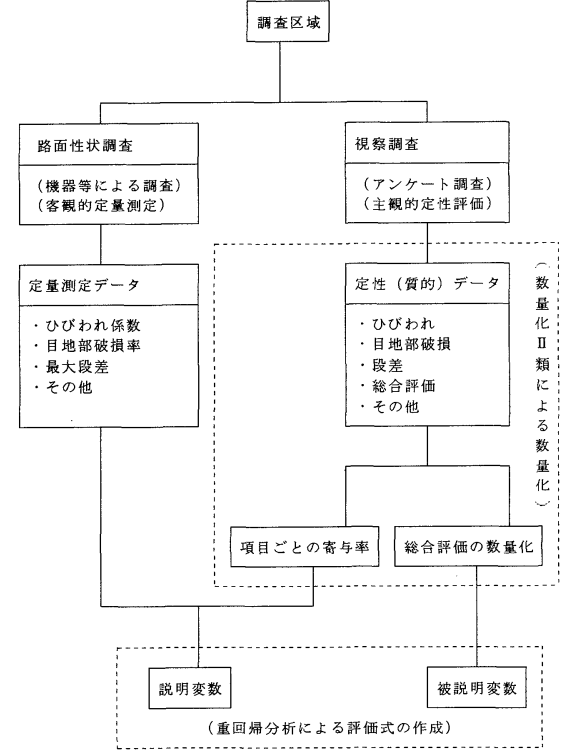

図一1 調査およびデータ分析の流れの概要

数 $\mathrm{CR}$ を求めた.

$\mathrm{CR}\left(\mathrm{cm} / \mathrm{m}^{2}\right)=\frac{\text { ひびわれ総延長 }(\mathrm{cm})}{\text { 調査区画の面積 }\left(\mathrm{m}^{2}\right)}$

(2) 目地部の破損率 $(\mathrm{JR})$ : 目地部の破損延長 $(\mathrm{cm})$ を測定し，次のように定義した目地部の破損率 JR を求 めた。

$\mathrm{JR}(\%)=\frac{\text { 目地部の破損延長 }(\mathrm{cm})}{\text { 目地部の総延長 }(\mathrm{cm})} \times 100$

(3) 最大段差 (SV) : 約 $5 \mathrm{~mm}$ 以上の段差を測定し, そのうちの最大のものを最大段差 $\mathrm{SV}(\mathrm{mm})$ とした.

(4) その他の測定項目 : スケーリング率, 平坦性,パッ チング率等を測定した。

\section{（2）視察調查（定性評価）}

この調査は各調査員（回答者）が路面をみたときにど のように評価するかをみるアンケート調査である．視察 調查は路面性状調査が行われたのと同じ調查区画に対し て同時期に実施した。調查員の総人数は 50 名であり, その属性と経験年数を図一2に示した。

視察評価項目として，路面性状を視察するときに調查 員が一般に注目する項目および定量測定項目と対比しゃ すい項目として表一1の(1) (5) が選定された. 評価項 目(1) (5)をその程度に応じて A， B，C，D のランクに 分け，対象とした調査区画の路面から各調査員が受ける 印象に最も近いランクに○印をつける方法を用いた．表 一1 の評価項目 (6) は，(1) （5) の評価をもとに，その区 画の舗装路面を総合的にどのように評価，判断するかを 調査するための項目である. また評価項目 (7) は，それ ぞれの場合の補修の必要性とその時期の判断のための総 


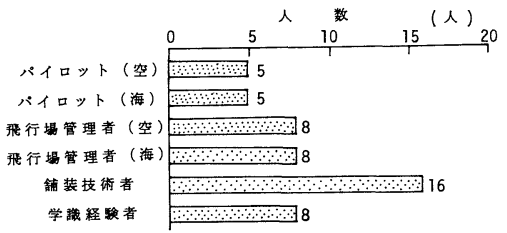

（a）回答者の禹性

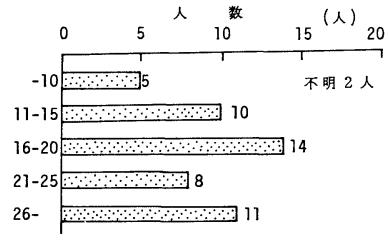

(b) 回答者の経铮年数

図一2 視察調査員の属性と経験年数

表一1 視察評価項目 (アンケート調查表)

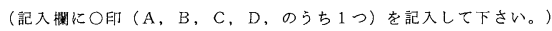

\begin{tabular}{|c|c|c|c|c|c|c|}
\hline & \multirow{2}{*}{ 目 } & \multirow{2}{*}{ 調 查 } & \multirow{2}{*}{ 郭 } & \multicolumn{2}{|c|}{ 価 } & \multirow{2}{*}{ 櫚 } \\
\hline 調 & & & & 定 & 備 & \\
\hline \multirow{4}{*}{\multicolumn{2}{|c|}{ (1) 絴・横断クラック }} & 全くない & A & & & \\
\hline & & わずかに見られる & B & & & \\
\hline & & かなり見られる & C & & & \\
\hline & & 著しい & $\mathrm{D}$ & & & \\
\hline \multirow{4}{*}{\multicolumn{2}{|c|}{ (2) 䦙角クラック }} & 全くない & $\mathrm{A}$ & & & \\
\hline & & わずかに見られる & $\mathrm{B}$ & & & \\
\hline & & かなり見られる & $\mathrm{C}$ & & & \\
\hline & & 著しい & $\mathrm{D}$ & & & \\
\hline \multirow{4}{*}{\multicolumn{2}{|c|}{ (3) 目地部の破損（角欠けなど） }} & 全くない & A & & & \\
\hline & & わずかに見られる & B & & & \\
\hline & & かなり見られる & c & & & \\
\hline & & 著しい & D & & & \\
\hline \multirow{4}{*}{\multicolumn{2}{|c|}{ (4) 目地部の断差 }} & 全くない & $\mathrm{A}$ & & & \\
\hline & & わずかに見られる & $\mathrm{B}$ & & & \\
\hline & & かなり見られる & C & & & \\
\hline & & 著しい & $\mathrm{D}$ & & & \\
\hline \multirow{4}{*}{\multicolumn{2}{|c|}{ (5) バッチング }} & 全くない & $\mathrm{A}$ & & & \\
\hline & & わずかに見られる & $\mathrm{B}$ & & & \\
\hline & & かなり見られる & C & & & \\
\hline & & 著しい & D & & & \\
\hline \multirow{4}{*}{\multicolumn{2}{|c|}{ (6) この調查区面の損伤程度 }} & 全くない & $\mathrm{A}$ & & & \\
\hline & & わずかに見られる & $\mathrm{B}$ & & & \\
\hline & & かなり見られる & c & & & \\
\hline & & 著しい & D & & & \\
\hline \multirow{4}{*}{ (7) } & \multirow{4}{*}{ ○䄇走路として見た場合 } & 必要なし & A & & & \\
\hline & & 柽微な補修の必要がある & B & & & \\
\hline & & 近いらち補修の必要がある & C & & & \\
\hline & & 早急に補修の必要がある & $\mathrm{D}$ & & & \\
\hline \multirow{8}{*}{$\begin{array}{l}\text { 補 } \\
\text { 修 } \\
\text { \% } \\
\text { 必 } \\
\text { 要 } \\
\text { 性 }\end{array}$} & \multirow{4}{*}{ ○䛾道路として見た埸合 } & 必要なし & $\mathrm{A}$ & & & \\
\hline & & 軽微な補修の必要がある & $\mathrm{B}$ & & & \\
\hline & & 近いらち補修の必要がある & $\mathrm{C}$ & & & \\
\hline & & 早急に補修の必要がある & D & & & \\
\hline & \multirow{4}{*}{ ○エプロンとして見た埸合 } & 必要なし & $\mathrm{A}$ & & & \\
\hline & & 軽微な補修の必要がある & $\mathrm{B}$ & & & \\
\hline & & 近いらち補修の必要がある & C & & & \\
\hline & & 早急に補修の必要がある & $\mathrm{D}$ & & & \\
\hline
\end{tabular}

合評価である.

\section{4. 視察調査の数量化}

今回の視察評価のように説明要因としての各評価項目 と従属要因 (外的基準) としての総合評価の両者が質的 データの場合には，それの数量化にあたっては一般に数 量化理論 II 類が用いられる ${ }^{21}$ 。まず，理論の要点を説明 しておこう.
いくつかの項目の評価から総合評価值を導くにあたつ て, 各評価項目の総合評価への寄与率が同じとは限らな いので, 計算された総合評価点と総合評価項目での評価 值とが矛盾することがある．そこで総合評価項目の評価 が同じデー夕 (回答) がなるべく同じ総合評価点になり, 総合評価項目の評価が異なるデー夕 (回答) はなるべく 離れた総合評価点となるように各項目の選択肢への点数 を付与する必要がある. すなわち, 表一1 の選択肢 A, $\mathrm{B}, \mathrm{C}, \mathrm{D}$ の 4 つ群がなるべくきれいに分かれるよう にする．まず，総合評価項目で $i$ と回答したデー夕群の うち, 第 $m$ 番目の総合評価点 $y_{i m}$ を次式で表わす.

$$
y_{i m}=\sum_{j=1}^{R} \sum_{k=1}^{k_{j}} a_{j k} \delta_{i m}(j k)
$$

ここに, $a_{j k}$ : 評価項目 $j$ の選択肢 $k$ に与えられる点数. $\delta_{i m}(j k)$ : 総合評価項目で $i$ と回答したデー夕の群のう ち第 $m$ 番目のデー夕が項目 $j$ の選択肢 $k$ に○印を付け たときには $1, k$ 以外の選択肢に反応したときには 0 を とる. $R$ : 全評価項目の数. $k_{j}$ : 各評価項目に含まれる 選択肢の数.

一方， $y_{i m}$ が群ごとにきれいに分けられるようにする には, 総合評価項目の 4 つの群の群間の変動が全変動に 対して最小になるようにすればよい．このことは相関比 诂を最大にすることになる。すなわち，

$$
\eta^{2}=\frac{S_{b}}{S_{t}}
$$

を最大にすることである．ここに， $S_{b}$ : 群間の変動, $S_{t}$ : 全変動. これを行列を用いて解くと, $a_{j k}$ は最大固 有值 $\eta^{2}$ に対応する固有ベクトルとして求められ, 各選 択肢の評価点となる。

今回の視察調査（アンケート調査）結果に上述の数量 化理論 II 類を適用して得られた数量化の結果が表一2で ある. 表一2の評価点が各項目の選択肢に与えられた点 数であり, 総合評価項目は 4 つあるので 4 通りの評価点 が与えられる.

\section{5. 数量化結果の考察}

\section{（1）相 関 比}

相関比が 1 に近いほど総合評価点と総合評価項目の評 価との結びつきが強く,4つの群がきれいに分かれたこ とを示している. 表一2において相関比は 0.545 から 0.691 であるが, 相関比は相関係数の 2 乗であることか ら，相関係数は 0.738 から 0.831 と読み換えることもで きる.このようなことから今回の視察調査結果について は解析に耐え得る数量化が行われたといえる.

(2) レン ジ

表一2 のレンジは同じ項目内の評価点のうち最大値か ら最小値までの幅である.この数字の大きいほどその項 
表一2 定性評価の数量化の結果（選択肢に与えられた評価点と レンジ)

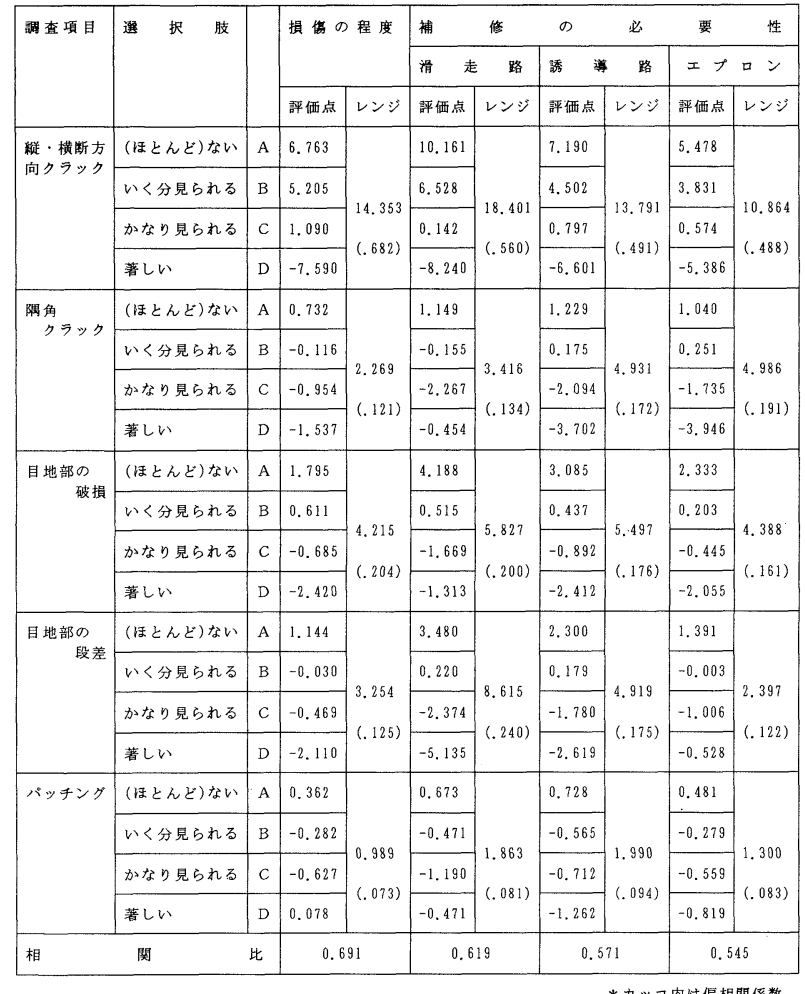

目の総合評価点に対する寄与率が大きいこと, すなわち 総合評価にあたって重要視される項目であることを示し ている. 表一2より, いずれの総合評価項目についても 「縦・横断方向クラック」の寄与率が大きく,「隅角ク ラック」,「目地部の破損」および「目地部の段差」の3 項目は少し考慮されている.「パッチング」はほとんど 影響を与えていないといえる。

\section{（3）境界値の設定}

総合評価点と定量測定結果とを結びつけて老朽度評価 式を作成する場合，総合評価の選択肢 A, B , C , D の 境界となるべき総合評価点を定めておく必要がある. と ころが相関比が 1 より小さいので, A〜Dの 4 つの群は 総合評価点によって完全に分かれてはいない. その状態 の例を示したのが図一3，4 である. 図一3，4 は「損傷 の程度」および「補修の必要性 (滑走路)」についての $\mathrm{A}, \mathrm{B}, \mathrm{C}, \mathrm{D}$ ごとの総合評価点の分布を示したものであ り，4つの群は総合評価点によって完全に分離されてい ないことがわかる.

そこで, 隣り合う群じうしの誤判別の数が等しくなる ように境界值を設定することにした，たとえば，Aと $\mathrm{B}$ の境界值については, 総合評価項目は $\mathrm{A}$ なのに総合 評価点では B となってしまうデー夕の比率と総合評価

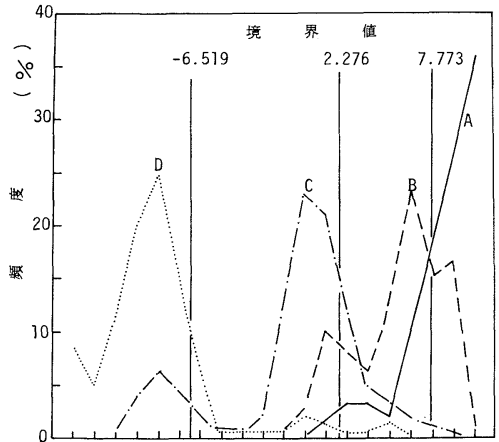

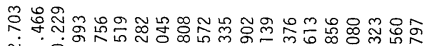

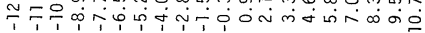
1 1 1 l 1 1 1 1 1 1 1 1 1 1 1 1 1 1 1 1

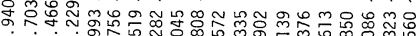

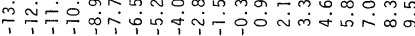

呼 価 点

図一3 総合評価点の分布（損傷の程度について）

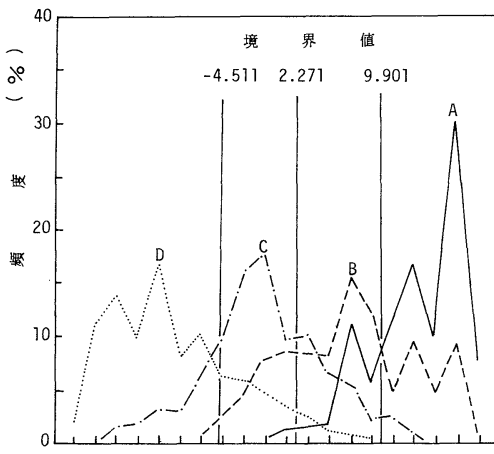

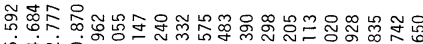

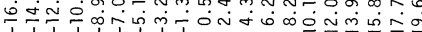

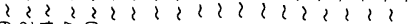

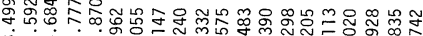

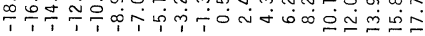

評価点

図一4 総合評価点の分布（滑走路の補修の必要性について）

\section{表一3 総合評価点のグループ分けの境界値}

\begin{tabular}{|c|c|c|c|c|}
\hline & $A と B$ & $B<C$ & CとD \\
\hline \multicolumn{2}{|c|}{ 損绩の程度 } & 7.773 & 2.276 & -6.519 \\
\hline \multirow{3}{*}{$\begin{array}{l}\text { 脯 } \\
\text { 修 } \\
\text { 号 } \\
\text { 必 } \\
\text { 要 } \\
\text { 性 }\end{array}$} & 滑走路 & 9.901 & 2.271 & -4.511 \\
\hline & 誘祩路 & 5.193 & 1.043 & -7.258 \\
\hline & エブロン & 3.242 & -1.191 & -7.286 \\
\hline
\end{tabular}

項目ではBなのに総合評価点では $\mathrm{A}$ となってしまう データの比率とが等しくなるように $\mathrm{A} と \mathrm{~B}$ の境界の総 合評価点を設定した。このようにして求められた境界值 を図一 3,4 に示すとともに表一3に一括して示した.な お，ここに示した境界值設定法による境界值の判別成功 率は $70 \%$ 以上であり，高い成功率であった。 


\section{6. 老朽度評価式の作成}

\section{（1）定量測定と定性評価の関係}

路面性状を視察した人がひびわれなどの路面破損の各 項目に対して，舗装が破損したと判断するのはそれらの 破損がざの程度進行した時点であろうか. アンケート調 查における評価項目の，たとえば $\mathrm{A}$ と $\mathrm{B} ， \mathrm{~B}$ と C の境 界が実測値とどのように対応するかを考えてみよう.

ある調査区画でのある項目の評価点として，表一2の 各評価点をその項目の $\mathrm{A}, \mathrm{B}, \mathrm{C}, \mathrm{D}$ のそれぞれに反応 した人数の比率で重み付けをした平均値を用いた。すな わち,

$$
e_{m}=\frac{P_{A} N_{A}+P_{B} N_{B}+P_{C} N_{C}+P_{D} N_{D}}{N_{A}+N_{B}+N_{C}+N_{D}}
$$

ここに, $e_{m}$ : 調査区画 $m$ におけるある項目の評価点, $P_{A} \sim P_{D}:$ おのおの評価 A D D に与えられた評価点, $N_{A}$ $\sim N_{D}$ : おのおの評価 $\mathrm{A} \sim \mathrm{D}$ と回答した人数.このよう にして求められた総合評価「損傷の程度」に関する評価 点 $e_{m}$ と実測値との関係の例を示したのが図一 $5,6,7$ である.ひびわれ係数は評価点と強い相関性があり, 目 地部の破損率と評価点の相関性もかなり高い.したがっ て，上記の両者は評価式の評価項目として十分と考えら れる. しかし, 段差と評価点との相関性は低く, 評価項 目として多少の問題を残しているといえよう.

\section{（2）３ 項目による評価式の作成}

数量化された視察総合評価に対して寄与率の大きい項 目の定量測定値（実測值）を用いた老朽度評価式として 次のような線形回帰を用いることにする.

$$
y=a_{0}+a_{1} x_{1}+a_{2} x_{2}+a_{3} x_{3}
$$

ここに $y$ : 各調査区画ごとの各回答者の総合評価点の平 均値, $a_{0} \sim a_{3}$ : 回帰係数, $x_{1} \sim x_{3}$ : 定量測定項目の実測 值. 評価式に取り入れる項目 $x_{1}, x_{2}, x_{3}$ としては, 先 に検討した各項目のレンジおよび偏相関係数から, 総合 評価にあたって重要だと判断され，かつ定量測定が比較 的容易であるという点を考慮して, ひびわれ係数 CR $\left(\mathrm{cm} / \mathrm{m}^{2}\right)$, 最大段差 $\mathrm{SV}(\mathrm{mm})$ および目地部の破損率 $\mathrm{JC}(\%)$ の 3 項目を選んだ。

評価式を導く手順は, まず表一2の各項目, 各選択肢 ごとの評価点を式 (1) に入れて, 各視察者の総合評価 点を計算し, その平均值を従属変数として各調査区画ご とに算出する. 次に各調查区画ごとのひびわれ係数, 最 大段差および目地部の破損率の実測值を独立変数とし て, 先の総合評価点の平均值に対して式 $(4)$ を用いて 重回帰分析を行う。したがって, 式 (4) の重回帰式が 損傷の程度および滑走路・誘導路・エプロンとしてみた 場合の補修の必要性に対して求められる。

求められた評価式（重回帰式）と決定係数（重相関係

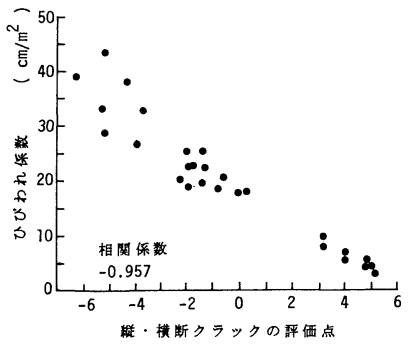

図一5 実測值と評価点の関係（ひびわれ）

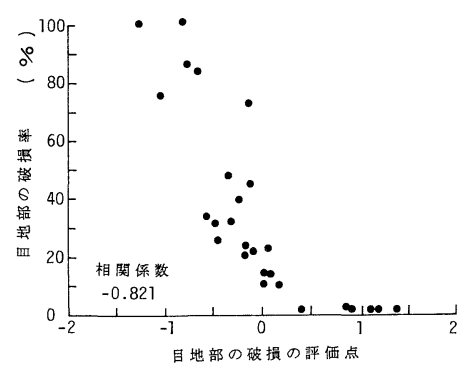

図一6 実測値と評価点の関係（目地部の破損）

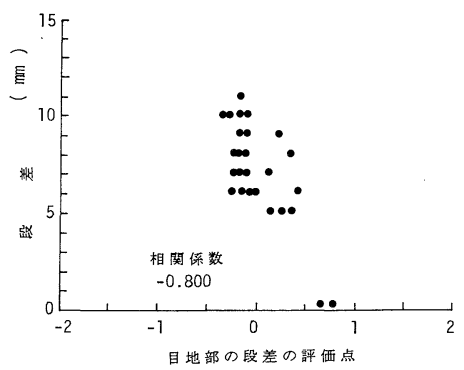

図一7 実測値と評価点の関係（段差）

表一4 重回帰分析による 3 項目評価式

(総合評価点の平均值を用いた場合)

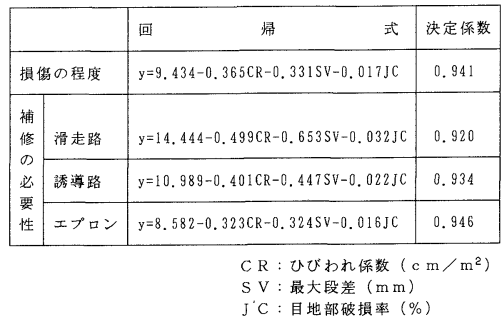

数）は表一 4 に示すようである. 今回の解析ではすべて の評価式の決定係数は 0.9 以上となっており, 右辺は左 辺を非常によく説明しているといえる.

説明変数である $\mathrm{CR}, \mathrm{SV}$ および JC の間の相関性が 高いと,たとえ決定係数が大きくても無意味な式になる. 説明変数間の相関係数は表一 5 のようになり，問題があ るほどに高い值でないことがわかる。一方，回帰係数 


\section{表一5 説明变数間の相関係数}

\begin{tabular}{|c|ccc|}
\hline & CR & S V & J C \\
\hline CR & 1.000 & & \\
S V & 0.397 & 1.000 & \\
J C & 0.045 & 0.310 & 1.000 \\
\hline
\end{tabular}

表-6 3 項目評価式と境界值（総合評価点の平均值 を用いた場合)

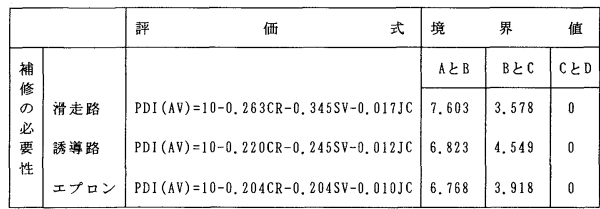

表一7 2 項目評価式と境界值 (総合評価点の平均値 を用いた場合）

\begin{tabular}{|c|c|c|c|c|c|c|}
\hline & & 式 & 決定係数 & 境 & 界 & 値 \\
\hline \multirow{4}{*}{ 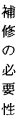 } & & \multirow{2}{*}{$\operatorname{PDI}(\mathrm{AV})=10-0.263 \mathrm{CR}-0.415 \mathrm{SV}$} & \multirow[b]{2}{*}{0.903} & Aと B & ВとC & CとD \\
\hline & 滑走路 & & & 7.722 & 3.634 & 0 \\
\hline & 誘溥路 & $\operatorname{PDI}(\mathrm{AV})=10-0.219 \mathrm{CR}-0.295 \mathrm{SV}$ & 0.923 & 6. 901 & 4. 601 & 0 \\
\hline & エプロン & $\mathrm{PDI}(\mathrm{AV})=10-0.203 \mathrm{CR}-0.246 \mathrm{SV}$ & 0.934 & 6.698 & 3.878 & 0 \\
\hline
\end{tabular}

$a_{0} \sim a_{3}$ について $\mathrm{t}$ 検定および $\mathrm{F}$ 検定を行ったところ, いずれの評価式においても危険率 $5 \%$ でクリアしてい る. 以上のことから，視察による総合評価が路面性状の 実測值によって合理的に精度よく説明されたといえる.

表一4 の評価式はそのままの形では使いにくく，利用 しやすい形に変換する必要がある. そこで，すべての測 定項目が 0 のき，すなわち舗装面に損傷がないときの 評価点 (指標) が 10 になるように式の変換を行った. 表一 6 が変換後の評価式である. 変換後の評価式によっ て得られる評価点をPDI (Pavement Deterioration Index）とよび，また，表一6の評価式を導くにあたっ ての重回帰分析において被説明変数の $y$ として総合評 価点の平均值を用いたことから，このときの評価点を PDI (AV) と表わすことにした.

\section{（3） 2 項目および単項目による評価式}

従来の舗装路面の破損調査においては 3 項目をすべて 測定している場合は少なく, 2 項目あるいは単項目の測 定実績が多い，そのような場合には，2 項目あるいは単 項目による評価式が必要になる. 2 項目評価式の作成に あたっては，3 項目評価式において説明力の高かったひ びわれ係数と最大段差を説明変数として用いることにし た. 得られた結果は変換後の評価式として境界值ととも に表一7に示した. また，単項目評価も同様にして求め ることができ，その結果を表一8に示した.

\section{（4）下側 $10 \%$ 值による評価式}

以上の評価式の作成においては, 重回帰分析の $y$ 亡
表一8 単項目評価式と境界值（総合評価点の平均値 を用いた場合)

\begin{tabular}{|c|c|c|c|c|c|c|c|}
\hline & & 産 & 式 & 決定係数 & 境 & 界 & 値 \\
\hline \multirow{4}{*}{$\begin{array}{l}\text { 補 } \\
\text { 修 } \\
\text { 必 } \\
\text { 要 } \\
\text { 性 }\end{array}$} & & \multirow{2}{*}{\multicolumn{2}{|c|}{$\operatorname{PDI}(\mathrm{AV})=10-0.385 \mathrm{CR}$}} & & $A と B$ & B と C & CとD \\
\hline & 滑走路 & & & 0.828 & 9.815 & 4. 619 & 0 \\
\hline & 誘道路 & \multicolumn{2}{|c|}{$\operatorname{PDI}(A V)=10-0.291 \mathrm{CR}$} & 0.863 & 8.134 & 5.423 & 0 \\
\hline & エプロン & \multicolumn{2}{|c|}{$\operatorname{PDI}(\mathrm{AV})=10-0.259 \mathrm{CR}$} & 0.884 & 7.668 & 4.439 & 0 \\
\hline
\end{tabular}

表-9 3 項目評価式と境界值（総合評価点の下側 $10 \%$ 值 を用いた場合）

\begin{tabular}{|l|l|l|l|l|l|l|}
\hline \multicolumn{2}{|c|}{} & \multicolumn{2}{|c|}{ 評 価 } & \multicolumn{1}{|l|}{ 決定保数 } & \multicolumn{2}{l|}{ 境 } \\
\hline
\end{tabular}

表-10 単項目評価式と境界值（総合評価点の下側 $10 \%$ 值 を用いた場合)

\begin{tabular}{|l|l|l|l|l|l|l|}
\hline \multicolumn{2}{|c|}{} & \multicolumn{1}{|l|}{ 評 価 } & 式 & 決定係数 & \multicolumn{2}{|l|}{ 境 } \\
\hline
\end{tabular}

して調査区画ごとの総合評価点の平均值を用いてきた. しかし，老朽度評価式の目的の中に安全性の確保が含ま れることを考えると，さらに厳しい評価をした人のデー 夕から得られる評価式にも興味がある.このような場合， 母集団の分布が特定できれば標準偏差等を用いることが 可能であるが, サンプル分布のパターンにばらつきがあ るのでそれは難しい，そこで，簡便法としてサンプル分 布の下側 $10 \%$ 值を用いて評価式を考えてみる.このよ うな考え方でサンプルの下側 $10 \%$ 值を用いて求められ た 3 項目評価式は表一9に示すようになる。 なお，下側 $10 \%$ 值を用いた評価式による評価点を PDI（10）と表 わすことにする.

同様にしてサンプルの下側 $10 \%$ 值を用いた場合の単 項目評価式は表一10のようである．表一9，10 の結果と も，平均值を用いたPDI (AV) よりも決定係数が低下 しており，精度が落ちていることがわかる.

\section{（5）下側 $20 \%$ 值による評価式}

今までの方法と同様にしてサンプル分布の下側 $20 \%$ 值を用いて作成された 3 項目評価式を表一11 に示した. なお，下側 $20 \%$ 值を用いて求められた評価式による評 価点をPDI（20）と表わすことにした. PDI（10）よ り決定係数は高くなっていることがわかる，下側 $20 \%$ 值を用いた単項目評価式を示したのが表一12である. 単項目によって総合評価を判断するので当然決定係数は 
表-113 項目評価式と境界值（総合評価点の下側 $20 \%$ 值 を用いた場合)

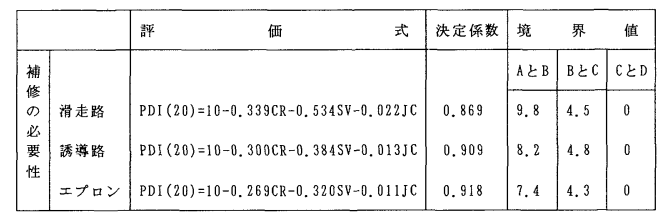

表一12 単項目評価式と境界值（総合評価点の下側 $20 \%$ 值 を用いた場合）

\begin{tabular}{|c|c|c|c|c|c|c|c|}
\hline & & 評 & 式 & 決定係数 & 境 & 界 & 值 \\
\hline \multirow{4}{*}{$\begin{array}{l}\text { 補 } \\
\text { 修 } \\
\text { の } \\
\text { 必 } \\
\text { 要 } \\
\text { 性 }\end{array}$} & & \multirow{2}{*}{\multicolumn{2}{|c|}{$\operatorname{PDI}(20)=10-0.591 \mathrm{CR}$}} & & Aと $B$ & BとC & CŁD \\
\hline & 滑走路 & & & 0.786 & 14.7 & 6.8 & 0 \\
\hline & 綉道路 & \multicolumn{2}{|c|}{$\operatorname{PDI}(20)=10-0.441 \mathrm{CR}$} & 0.835 & 10.6 & 6.3 & 0 \\
\hline & エプロン & \multicolumn{2}{|c|}{$\operatorname{PDI}(20)=10-0.374 \mathrm{CR}$} & 0.851 & 9.2 & 5.4 & 0 \\
\hline
\end{tabular}

小さく, 精度は低下する傾向にある.

\section{7. 得られた評価式の検討}

\section{（1）他機関の評価式との比較}

すでに述べたように，他機関等からも路面性状による 供用性評価式が提案されているが，これらは道路舗装あ るいはアスファルト舗装を対象とするものであったり， 路面性状の評価項目が違っていたりして, 評価式を直接 比較することが困難な場合が多い，運輸省が提案してい る空港のコンクリート舗装に関する評価指標 $\mathrm{PRI}^{5)}$ がこ こで得られた PDI と同じ形式であるので比較が可能で ある・

今回の調査対象である入間飛行場の各調査区画での実 測值を, ここで得られた滑走路の 3 項目評価式 (PDI) および運輸省の評価式 (PRI) に代入して得られた結果 を示したのが図一8である. 本研究で得られた評価值 (PDI) と評価内容において, 評価值 C「近いうちに補 修が望ましい」とは, 補修に着手してもよい時期に達し ていると考え, また, 評価值 D「早急に補修の必要が ある」とは, すでに補修がなされるべき状態に達してい ると解釈できよう. すなわち，PDIによる評価值 C と D は, PRI の評価值 C「できるだけ早急に補修の必要 がある」に相当すると考えることができる.

このような判断に基づいて PDI と PRI を比較する と, 総合評価点分布の下側 $20 \%$ 值を用いたPDI (20) あるいは平均値を用いたPDI (AV) が PRI とほぼ同程 度の評価を与えている.ここには示してないが, PDI とPRIの相関は，ひびわれ係数および段差の影響を受 けている破損状況の場合にはかなりよい相関性を示す が，目地部の破損率の影響が大きい破損状況の場合には 相関性が低下する傾向がみられた。

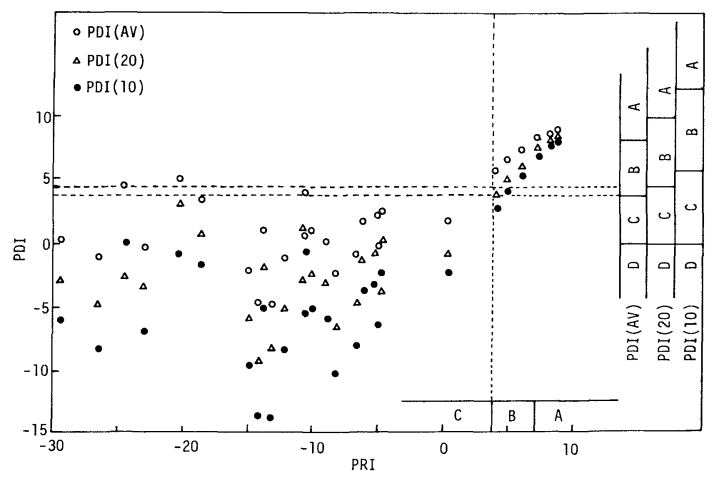

図一8 PDI と PRIの比較（入間飛行場の調查結果より, 滑走路としてみた場合について)

\section{表一13 単項目評価值 B と C の境界值とひびわれ係数}

\begin{tabular}{|c|c|c|}
\hline 単項目誈価式 & BとCの境界值 & ひびわれ俰数 $\left(\mathrm{cm} / \mathrm{m}^{2}\right)$ \\
\hline $\operatorname{PDI}(\mathrm{AV})$ & 4.6 & 14.0 \\
\hline $\operatorname{PDI}(20)$ & 6.8 & 5.4 \\
\hline $\operatorname{PDI}(10)$ & 9.1 & 1.1 \\
\hline
\end{tabular}

\section{（2）既存調查資料と補修実績による評価式の検討}

従来より防衛庁においても多くの飛行場に関して舗装 の破損調査が行われてきている8 . しかし, 調查の大部 分が単項目, 特にひびわれの調査であるため,ここでの 検討も単項目評価が主体とならざるを得なかった.

滑走路に関する単項目評価式 PDI (AV), PDI (20) および PDI（10）による評価值 B と C の境界を補修に 着手する時期として, これらの境界值に対応するひびわ れ係数を求めると表一13となる.たとえば, PDI (AV) によれば,ひびわれ係数が $14.0 \mathrm{~cm} / \mathrm{m}^{2}$ になると評価值 が 4.6 になり, 補修に着手する時期に達していることを 示している.

実際に補修が行われたときの滑走路のひびわれ係数 CR と単項目評価による PDI の関係を示したのが図一 9，10および 11 である. 図において，○印は基準以上 のひびわれ係数に達しているもの，○印は基準以下のひ びわれ係数を示している. 過去の補修実績においては, これらの図に示したひびわれ係数において, 補修の必要 ありと判断されて工事が行われている. 図中には運輸省 のひびわれ係数の単項目評価式 $\mathrm{PRI}^{1}{ }^{1}$ による補修に必要 なひびわれ係数の值 $5.6 \mathrm{~cm} / \mathrm{m}^{2}$ も示しておいた.

これらの図より, PDI (AV) を用いた場合には, 路 面性状が補修必要と判断され, 実際に補修された直前の ものであるのに，データの大部分が PDI (AV) による 評価值 $4.6\left(\mathrm{CR}=14.0 \mathrm{~cm} / \mathrm{m}^{2}\right)$ 以上となっており, 評 価值 Bとなってしまう. すなわち, 軽微な補修の段階 にあると評価されている。このように, PDI (AV) は 


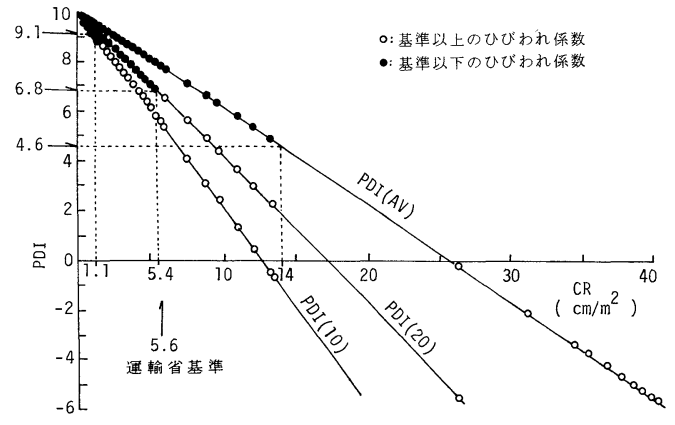

図一9補修実績による PDIの適合性（その 1)（単項目評価, 滑走路について)

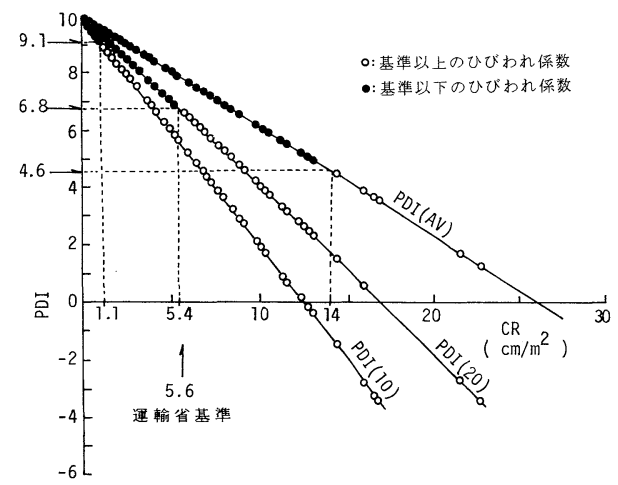

図一10 補修実績によるPDI の適合性（その2）（単項目評価, 滑走路について)

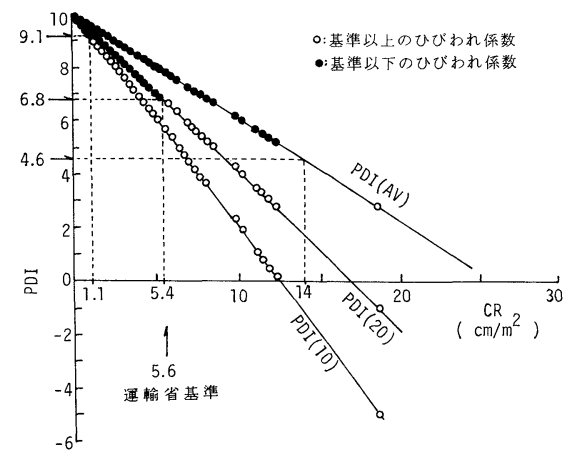

図一11補修実績によるPDIの適合性（その3）（単項目評価, 滑走路について)

老朽度評価式としては実際と適合しない点があるといえ よう。一方, PDI（10）はかなり軽微な損傷の段階 ( $\mathrm{CR}$ で $1.1 \mathrm{~cm} / \mathrm{m}^{2}$ 程度) から補修に着手しなければな らないと評価されており，実態とかけはなれたものと なっている，すなわち，PDI（10）は必要以上に過大な 評価を与えている.PDI (20) を用いた場合には, 全デー 夕の約 30〜 40\% が評価値 Cになり, 補修直前の舗装の 損傷の実情をほぼ啇切に評価していると考えられる。

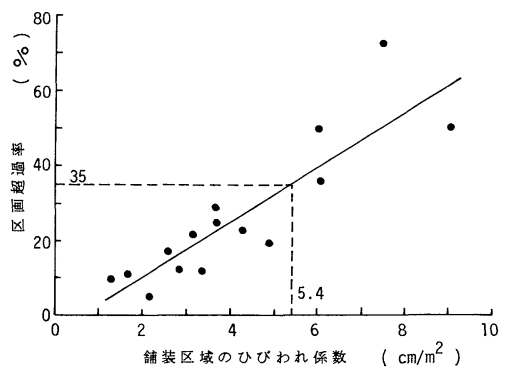

図一12 補修実績による区画超過率とひびわれ係数の関係 (滑走路について)

図一12 は，過去の防衛庁の補修実績に基づいて，調 查対象の舗装区域のひびわれ係数と, 舗装区域の全調査 区画に対してひびわれ係数が $5.4 \mathrm{~cm} / \mathrm{m}^{2}$ を越える調査 区画の比率（ここでは区画超過率とよぶことにする）と の相関を示したものである. 図一12より，単項目評価 PDI（20）によって補修に着手する評価 B と C の境界 に相当するひびわれ係数 $5.4 \mathrm{~cm} / \mathrm{m}^{2}$ に対応する区画超 過率は約 $35 \%$ となっていることがわかる．言い換えれ ば，ひびわれ係数 $5.4 \mathrm{~cm} / \mathrm{m}^{2}$ の区画超過率が，約 $35 \%$ を越えたときを, 調查対象の舗装区域の補修着手時期と している.

3 項目評価式については, 既往の調査測定データがな いので補修実績との直接の比較検討ができなかった。し かし，単項目評価による補修実績との比較あるいは運輸 省の評価値との比較から，現段階では総合評価点分布の 下側 $20 \%$ 值を用いたPDI（20）の評価值が最も適当で あると考えられる。

\section{8. まと め}

本研究では, 飛行場コンクリート舗装の破損に関する 路面性状調査と視察調查を実施し, 収集したデー夕の数 量化分析加 , 舗装の老朽度に関与する破損項目の選定 とその寄与率を明らかにし，老朽度の評価式を提案し， それの適合性を検討した，得られた結果を要約すると以 下のようである.

（1）数量化分析の基礎データとしての視察による定 性評価に関しては，舗装技術者のみならず利用者の立場 のパイロット，飛行場の管理者および学識経験者の評価 を幅広く取り入れた。

（2）視察調查（アンケート調査）による主観的な定 性評価について数量化理論 II 類を用いて数量化を行っ た。 その結果, 舗装の総合評価に与える損傷の種類と程 度の寄与率が明らかにされ，かなりよい精度の数量化を 行うことができた.

（3）視察調査による定性評価の数量化の結果と実測 による定量測定値を用いて重回帰分析を行い，路面性状 
に基づく老朽度評価式（3 項目，2 項目および単項目評 価式）を作成した。 そのとき，評価式に取り入れる総合 評価の基準として, 総合評価点分布の平均值, 下側 20 $\%$ 值および下側 $10 \%$ 值を用いた場合の 3 通りについて 検討し, それらのおのおのの場合について老朽度評価式 を作成した。

（4）過去の補修実績との比較あるいは他機関（運輸 省）の評価式との比較を行い, 得られた老朽度評価式の 適用性を検討した. その結果, 総合評価の基準として, 総合評価点分布の下側 $20 \%$ 值を用いた評価式が, 過去 の補修実績あるいは他機関（運輸省）の評価式と最も適 合性が高いことがわかった。

（5）調査対象区域全体を評価する場合には，補修の 基準を越える評価值となる調査区画数の全調査区画数に 対する比率 (区画超過率) で考える必要があり, 過去の 補修実績によると, 区画超過率が約 $35 \%$ に達したとき に対象区域全体の補修に着手すべきことがわかった。

ここで検討した路面性状による老朽度評価方法は，も ちろん完全なものではない。さらに, PDIの適用限界 を定めたり, 限界值をより実用的なものにして, 老朽度 評価基準を合理的なものに育てていくためには，実際の 飛行場での補修工事との比較検討を続けていくととも に, 調査人員を減らした場合の精度の問題も検討してい く必要がある.
最後に，本研究にあたり，運輸省港湾技術研究所の佐 藤勝久博士から種々ご教示をいただいた．深く感謝する 次第である. また，視察調査を始めとする各段階で関係 各位のご協力を賜った.

\section{参 考 文 献}

1）福手 勤・佐藤勝久 -八谷好男 - 山崎英男：路面性状に よる空港舗装の供用性評価, 港湾技術資料, No. 414, 1982.

2) 田中 豊-脇本和昌 : 多変量統計解析法, 現代数学社, pp. 151 160, 1983.

3）たとえば, 植木 協・加藤 晃: 道路工学, 朝倉書店, pp. 137 140, 1972.

4）飯島 尚・今井 博・猪股和義：MCI による舗装の供用 性の評価，土木技術資料，23-11，pp. 15 20, 1981.

5）運輸省航空局 : 空港舗装補修要領 (案), pp. 41 44, 1984.

6) Epps, J.A. et al. : Roadway maintenance evaluation user's mannual, Research Report 151-2, Texas Transportation Institute, Texas A \& M University, p. 39, 1971.

7) Shahin, M.Y. and Darter, M.I. : Condition evaluation of jointed concrete airfield pavement, Proc. of ASCE, TE4, pp. 381 399, 1980.

8）新井弘文・荒井直人: 飛行場コンクリート舗装の破損特 性について, 防衛庁土木技術研究会報, 第 10 号, pp. 117 133, 1970.

(1989. 8. 21 • 受付) 